\title{
Erratum
}

\section{Water and Leaching Requirements of Industrial Tomatoes Irrigated with Brackish Water}

\author{
A. Vinten, J. Shalhevet, A. Meiri, and J. Peretz \\ Department of Environmental Physiology and Irrigation Institute of Soils and Water, \\ Agricultural Research Organization, The Volcani Center, P.O.B. 6, Bet Dagan 50-250, Israel \\ Irrigation Science (1986) 7:13-25
}

Due to an unfortunate oversight the above article was printed without the author's proof corrections being taken into consideration. The article therefore contained the following errors:

1. The Summary should have included the first paragraph of the main body of the text. The text should then have begun, "A large body of information ..."

2. On page 13, in the text between Eq. (1) and Eq. (2), the abbreviation for change in soil water storage should be $\Delta S$.

3. On page 14 , line 2 , " $y_{\max }$ " should read " $Y_{\max }$ ".

4. In the first line of the third paragraph of the Materials and Methods section, "1 1/h drippers" should be "2 1/h drippers".

5. Line 4 at the head of Table 1 should read "Days 21-48 (drip), $90 \mathrm{~mm}$ applied every 4-5 days".

6. In the text below Eq. (5) at the bottom of page 16 and in line 3 on page $18, " \partial_{\nu}$ " should read " $\theta$ ".

7. Throughout the section headed "Water Balance" under Results and Discussion the abbreviation for soil water storage change should read " $\Delta S$ ".

8. A corrected version of Table 3 is printed on the next page. 
Table 3. Final electrical conductivity of the saturation extract $\left(\mathrm{EC}_{\mathrm{e}}\right)$. Means of three replications unless otherwise indicated in parenthesis. Samples taken in plant row, $(\mathrm{d} S / \mathrm{m})$

\begin{tabular}{|c|c|c|c|c|c|}
\hline \multirow{2}{*}{$\begin{array}{l}\text { Water } \\
\text { quality } \\
\text { treatment }\end{array}$} & \multirow{2}{*}{$\begin{array}{l}\text { Soil } \\
\text { depth } \\
\text { m }\end{array}$} & \multicolumn{4}{|c|}{ Water quantity treatment } \\
\hline & & A & $\mathrm{C}$ & $\mathrm{E}$ & G \\
\hline \multirow{6}{*}{$\begin{array}{l}\mathrm{S}_{0} \\
1.1 \mathrm{dS} / \mathrm{m} \\
\text { (All } 1 \mathrm{rep} \text {.) }\end{array}$} & $0-0.15$ & 5.3 & 1.3 & 2.2 & 2.7 \\
\hline & 0.30 & 4.3 & 1.0 & - & 2.8 \\
\hline & 0.60 & 4.2 & 1.2 & 1.5 & 1.9 \\
\hline & 0.90 & 3.1 & 1.4 & - & 3.1 \\
\hline & 1.20 & 1.9 & - & - & 2.8 \\
\hline & Mean & 3.8 & 1.2 & (1.9) & 2.7 \\
\hline \multirow{6}{*}{$\begin{array}{l}S_{1} \\
5.9 \mathrm{dS} / \mathrm{m}\end{array}$} & 0.15 & 6.3 & 5.2 & 5.6 & $3.9(2)$ \\
\hline & 0.30 & 6.5 & 3.3 & 6.9 & $3.9(2)$ \\
\hline & 0.60 & 4.9 & 3.0 & 4.3 & $2.9(1)$ \\
\hline & 0.90 & 3.3 & 3.0 & 4.3 & $2.4(2)$ \\
\hline & 1.20 & 2.5 & 3.5 & 3.0 & $2.6(2)$ \\
\hline & Mean & $4.7 \pm 1.1$ & $3.6 \pm 0.6$ & $4.8 \pm 1.1$ & $3.1 \pm 0.1$ \\
\hline \multirow{6}{*}{$\begin{array}{l}\mathrm{S}_{2} \\
8.1 \mathrm{dS} / \mathrm{m}\end{array}$} & 0.15 & $5.9(2)$ & 6.6 & 5.3 & 5.8 \\
\hline & 0.30 & $8.9(2)$ & 7.1 & 5.0 & 5.7 \\
\hline & 0.60 & $8.8(2)$ & 4.8 & 3.8 & 5.6 \\
\hline & 0.90 & $7.1(2)$ & 4.3 & 4.3 & 4.5 \\
\hline & 1.20 & $1.8(1)$ & 3.7 & 3.8 & 3.3 \\
\hline & Mean & $6.5 \pm 4.9$ & $5.3 \pm 0.4$ & $4.4 \pm 0.9$ & $5.0 \pm 1.3$ \\
\hline
\end{tabular}

No values of $S E$ for $1.1 \mathrm{dS} / \mathrm{m}$ because there was only one replicate. Differences between $\mathrm{S}_{1} \mathrm{C}$ and $\mathrm{S}_{2} \mathrm{C}$, and between $\mathrm{S}_{1} \mathrm{G}$ and $\mathrm{S}_{2} \mathrm{G}$, are significant at $p=0.05$ 